University of Nebraska - Lincoln

DigitalCommons@University of Nebraska - Lincoln

Papers in Systematics \& Biological Diversity

Papers in the Biological Sciences

December 1880

\title{
A Sketch of the Progress of Botany in the United States in 1880
}

Charles E. Bessey

University of Nebraska - Lincoln

Follow this and additional works at: https://digitalcommons.unl.edu/bioscisystematics

Part of the Other Life Sciences Commons

Bessey, Charles E., "A Sketch of the Progress of Botany in the United States in 1880" (1880). Papers in Systematics \& Biological Diversity. 6.

https://digitalcommons.unl.edu/bioscisystematics/6

This Article is brought to you for free and open access by the Papers in the Biological Sciences at DigitalCommons@University of Nebraska - Lincoln. It has been accepted for inclusion in Papers in Systematics \& Biological Diversity by an authorized administrator of DigitalCommons@University of Nebraska - Lincoln. 


\title{
A SKETCH OF THE PROGRESS OF BOTANY IN THE UNITED STATES IN 1880.
}

\author{
BY PROFESSOR C. E. BESSEY.
}

A. Anatomy and Pliysiology. - A valuable paper appeared in the Botanical Gazette for November, on "The Stem of the Pumpkin for illustrating Plant Histology," by J. C. Arthur. The disposition of the various tissues, with notes upon some of their peculiarities, and suggestions as to the best methods of preparing them for observation, make up the bulk of the paper. Finally a classified list of the tissues is given, as follows:
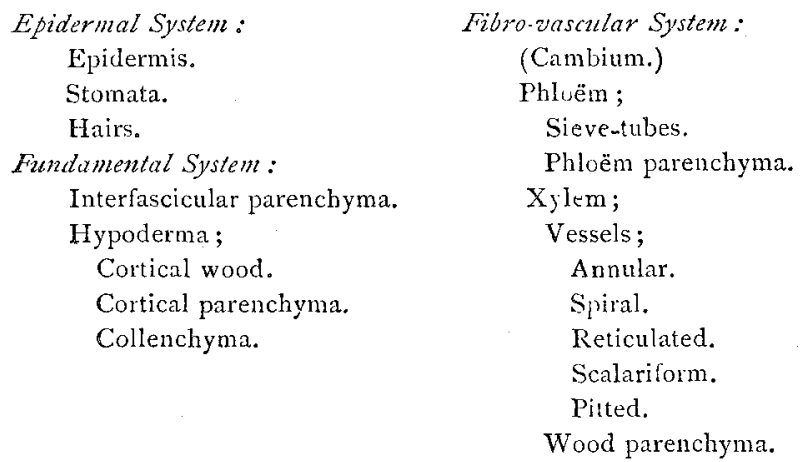

"To these should doubtless be added Laticiferous tissue, sometimes detected in the phloëm."

W. K. Higley, in two papers published in the Naturalist for Oct. and Nov., added somewhat to our knowledge of the "Microscopic Crystals contained in Plants." Many crystal-containing plants are noted, and a useful list is given of all the natural orders of plants in which these structures have been observed.

Dr. Engelmann's paper on "The Acorns and their Germination," published in the Transactions of the St. Louis Academy of Sciences, Vol. rv, records the results of his careful study of the germination of the acorns of many species. In addition to a definite statement of the structure of the embryo in the species examined, the author describes the tuber-like enlargement of the radicle in the live-oak, caused by the transfer to the latter of the food from the cotyledons.

In a paper on "The Supposed Dimorphism of Lithospermunm longiftorum," by C. E. Bessey, published in the June number of the Naturalist, the writer showed by means of many measurements that this species is not dimorphic (heterostylous), but that 
948 Progrcss of Botany in the United States in 1880 . [December,

its large flowers are exceedingly variable as to length of corolla and style.

Thomas Meehan's "Dimorphic Flowers in Houstonia" and "Cleistogamy in Oxalis acetosella," and I. C. Martindale's "Sexual Variation in Castanea Americana," published in the Proceedings of the Academy of Natural Sciences of Philadelphia, should be noted here as interesting contributions to this department of botany. The "Notes on the Flowering of Saxifraga sarmentosa," by Professoir J. E. Todd, in the August Naturalist, are somewhat more extended than the preceding, and accompanied by several wood-cuts.

"Nectar and its Uses," published by Wm. Trelease in the Report upon Cotton Insects, issued by the Department of Agriculture, is a carefully prepared essay, bringing together what is known as to the production and uses of the nectar of plants. A plate and an excellent list of the books and papers treating of nectar, add to the usefulness of the essay.

Professor W. J. Beal published in the March number of the Naturalist, some notes on the "Agency of Insects in Fertilization." These notes were made by students under the guidance of the professor, and many of them are admirable.

Wm. Barbeck, in the Proceedings of the Academy of Natural Sciences of Philadelphia, published a paper on "The Development of Lemna," in which he concludes that in Lemna "we have an interesting instance of parthenogenesis, there being seeds (produced in autumn by a sexual process) from which, during the course of the summer, generation after generation is propagated without any further fertilization."

Here shuuld be mentioned Dr. Gray's note on the "Automatic Movement of the Frond of Asplenium trichomanes," published in the Botanical Gazette for March, and W. K. Higley's notes on "Carnivorous Plants" (Drosera rotundifolia) in the December number of the same journal.

B. Systematic Botany.-a. Fungi. In the March number of the Botanical Gazette, C. H. Peck described nineteen new species of fungi, mostly from the Eastern United States. These are an interesting Stemonitis (S. Morgani) which is closely related to $S$. fusca; Coniotluyrium minutulum, Leptothyrium chromospermum, Phoma albistrata, Phoma colorata, Septoria consocia, Septoria irregulare, Discella variabilis, Sporidesmium minutissimum, Lecythea 
macrosora, Acidium Famesianum, Sorosporium atrum on a Carex, from Pennsylvania and Colorado, Cheironyces tinctus, Peziza spongiosa, Phacidium sparsum, Stictis fulva, Diatrype angulare, Spharia altipeta, Spheria lichenalis.

Twenty-nine new species of fungi, collected in California by Dr. Harkness, were described by M. C. Cooke in the September number of Grevillea. The descriptions are mere Latin diagnoses, and are by no means satisfactory. The species described are Phoma hosackiee, Chatophoma atriella, Vermicularia sitbglabra, Septoria helianthicola, Discella olivacea, D. temuispora, Diplodia microscopica, D. rhuina, Hendersonia galionum, Dichonera phacelie, D. compositarum, Gleosporizm legunninis, Torula glutinosa, Coleosporium baccharidis, Macrosporum culmorum, Trichä̈gum atrum Preuss., T. opacum, Fusarium gallinackum, Leotia ochroleuca, Stictis decipiens Karst., S. radiata, var. pumila, S. annulata C. and Phil., Ascomyces fulgens, Spharia labiatarun, S. epipteridis, Spharella brachytheca, S. aralie, S. dendroneconis, S. acacice. All, with three exceptions indicated above, are described as by Cooke and Harkness, who are therefore to be quoted as the joint authors of the specific names.

M. C. Cooke enumerated thirty-one species of "New York Fungi," of which seven were new, in the March number of Grevilled. The new species which are described are the following: Coniothyrium rubellum, Diplodia celastri, D. compressa, Massaria Gerardi, Psilospharia melasperma, Conisphario peniophora, Spharella ilicella.

Two new species of Septoria were described by Baron F. De Theumen in the October Botanical Gazette, one (S. Albaniensis) on Salix from New York, and the other (S. Querceti) on Quercus from South Carolina.

An interesting addition to the Phalloidei was made in an article on "A New Fungus," by W. R. Gerard, in the January Bulletin of the Torrey Botanical Club. The new species, Simblum rubescers, was discovered on Long Island. A full and satisfactory description is given, and two good plates are added. Appended to the paper is a valuable "List of United States Phalloidei," including all "which have been detected in the United States up to the present time."

The "Catalogue of Pacific Coast Fungi," by Dr. Harkness and J. P. Moore, first read before the California Academy of Sciences, 
950 Progress of Botany in the United States in 1880 . [December,

Feb. 2, I880, and afterwards published in a pamphlet of fortysix pages, enumerates nearly 900 species. Localities and habitat are given for the greater number of the species. One new species, Agaricus tridens Moore, from a drift 400 feet below the surface, is described.

A valuable article on "The White-grub Fungus," appeared in the June number of the American Entomologist. The writer (C. $\mathrm{V}$. Riley) appended a list of papers containing references (mostly popular) to this fungus. Two wood-cuts accompany the article.

Professor Prentiss' paper in the August and September NatuRALIST, on the "Destruction of Obnoxious Insects by means of Fungoid Growths," recorded the results of a series of experiments with yeast as an insecticide. The results were plainly adverse.

Professor Burrill's paper on "Anthrax of Fruit-trees," read before the Boston meeting of the American Association for the Advancement of Science, did not reach the public, through the tardy publication of the "Proceedings," until about a year later. Abstracts appeared in various journals, one of which, viz., that in the Anerican Monthly Microscopical Fournal, is selected for notice here. The disease called blight is held, by Professor Burrill, to be due to "a living organism which produces butyric fermentation of the material stored in the cells, especially those in the liber. This organism is allied to, if not identical with the butyric vibrione of Pasteur, and the Bacillus anylobacter of Van Tieghem." Experiments were made by inoculating healthy trees, and the results appeared to sustain the theory of the bacterial nature of the disease. The bacteria observed were described, and careful measurements given.

Century IV of Ellis' now well-known "North American Fungi," was issued during the year.

6. Alga. Francis Wolle's paper on "Fresh-water Algx," in the April Bulletin of the Torrey Botanical Club, contained a "list of upwards of one hundred plants, at least ninety of which are new to the United States, and of which eighteen were wholly unknown." The new species described are the following: Spharozyga saccaia, Tolypothrix bombycina, Euastrum Donnelli, E. formosum, Micrasterias Kitchelli, Staurastrum pulchrum, St. Nova-Casarea, St. tricornutum, St. macrocerum, St. fasciculoides, St. subarcuatum, St. comptum, St. pusillum, Arthrodesmus fragilis, Pleurocarpus tenuis, Elogonizm Donnelli. In the August num- 
ber of the same journal the same author publishes a plate containing good figures of all the new desmids in the preceding list.

Dr. Farlow's paper "On some Impurities of Drinking-water caused by Vegetable Growths," published in the First Annual Report of the Massachusetts State Board of Health, contributed to our knowledge of the economic relations of the fresh-water algæ to ourselves. Two plates accompany this valuable paper.

Dr. T. F. Allen's "Characeæ Americanæ Exsiccatæ," consisting of dried specimens of ten species of Characeæ, was issued late in the year. The species are Nitella tenuissima Desv., $N$. intermedia Nordst., $N$. megacarpa Allen, Chara intermedia A. Br., Ch. intermedia A. Br., var. Americana A. Br., Ch. contraria A. Br., Ch. sejuncta, A. Br., Ch. coronata A. Br., var. Schweinitzii A. Br., Ch. gymnopus A. Br., var. Michauxii A. Br., Ch. hydropitys A. Br., var. septentrionalis, Nordst.

c. Lichenes. Our lichenologists appear to have published nothing during the year.

d. Bryoplyytes. A severely critical paper entitled "Bryological Notes and Criticisms," by the lamented Coe F. Austin, appeared in the January Bulletin of the Torrey Botanical Club. It was suggested by the study of a paper by Lesquereux, James and Schimper containing descriptions of new species of North American Mosses. Mr. Austin challenged many of the new species described in the paper under review.

Mr. Austin published a paper, Bryological Notes, in the February number of the Bulletin, consisting of critical notes upon several species of mosses and several descriptions. The new genera Donnellia and Rauia were announced (but not described) and descriptions were given of Donnellia Floridana and Thuidium Alleni.

The "Catalogue of North American Musci," by E. A. Rau and A. B. Hervey, enumerates 1237 species. Localities are given for all the species.

e. Pteridophytes. Professor D. C. Eaton's magnificent work, "The Ferns of North America," was brought to a close early in the year. The beautiful plates, by Emerton and Faxon, and the clear and satisfactory descriptions are notable features in this great contribution to our knowledge of the ferns of this country.

In the June Bulletin of the Torrey Botanical Chub, Professor Eaton, under the title of "New or Little-known Ferns of the United 
States," notices several species, and describes one new one, Notholana Lemmoni, from Arizona. The same author's "Systematic Fern List," a twelve page pamphlet, appeared in September. It consists of "a classified list of the known ferns of the United States of America, with the geographical range of the species." One hundred and fifty-one species and sixteen varieties are included.

In "A New Fern," by G. E. Davenport, in the Bulletin of the Turrey Botanical Chub, the author describes a new species (Notholana Grayi) from Southeastern Arizona. A fine plate by Faxon accompanies the paper.

f. Phanerogans. Dr. Gray's "Contributions to North American Botany," published in the Proceedings of the American Academy of Arts and Sciences, Vol. xvI, is principally devoted to "Notes on some Compositæ." Synopses of species are given for the genera Aphanostephus, Chætopappa, Townsendia and Erigeron, and important notes are included under Vernonia, Solidago and Aster. Two new genera, Greenella and Grundlachia, and a number of species are described. Six new species of Asclepias are noted, and a new genus (Geniostemon) with two species of Gentianaceæ are described. Descriptions of miscellaneous species, and of a new genus of Euphorbiaceæ (Reverchonia) complete this valuable contribution.

Dr. Gray also published a synopsis of the species of the genus Leavenworthia, in the March Botanical Gazette.

A most important paper from Dr. Geo. Engelmann, entitled a "Revision of the genus Pinus, and Description of Pinus Lilliottii," was published in the Transactions of the Academy of Sciences of St. Louis, Vol. IV. The characters of pines are carefully described in extenso, and upon these a new arrangement of the species is proposed. The characters of the fruit scale serve to separate the genus into two sections, viz: I. Strobus ("Apophysis with a marginal unarmed umbo, generally thinner"), and Ir. Pinaster ("Apophysis with a dorsal umbo, mostly armed, generally thicker"). "The subsections are distinguished by the position of the ducts within the leaf." The description of Pinus Elliottii, a south eastern species, is all that could be desired, and this is supplemented by three large and most excellent plates.

In the January Botanical Gazette, Dr. Engelmann described, in full, the northern Catalpa, Catalpa speciosa, which had previously been considered to be $C$. bignonicides. 
Several new species of the genus Potamogeton were described by Thomas Morong, in the May Botanical Gazette. The new species are $P$. Illinoensis, $P$. Mysticus, $P$. lateralis, and $P$. gemmiporrus (the latter by Robbins). Notes are added upon several other species.

I. C. Martindale, in a pamphlet entitled "Notes on the Bartram Oak, Quercus heterophylla Michx." reviewed the whole history of this much discussed and doubted species, and concluded that it should be restored as a true species.

Professor Sargent's "Preliminary Catalogue of the Forest Trees of North America," contained 342 species, with notes as to size, range, economic uses, etc.

Mention should be made here of H. W. Patterson's "Check List of N. A. Gamopetalæ after Compositæ," designed for use in making exchanges, marking desiderata, etc.

Robinson's "Flora of Essex county, Massachusetts," Smith and Mohr's "Preliminary List of the Plants growing without cultivation in Alabama," Peck's "Plants of the Summit of Mt. Marcy" (from the 7 th Rept. of the Adirondack Survey), the list of "Ballast Plants in and near New York city," by Addison Brown, in the December Bulletin of the Torrey Botanical Club, are valuable additions to our knowledge of local floras. Here may be noted the beginning, in the last named journal, of an important List of the State and local foras of the United States, by W. R. Gerard and N. L. Britton.

C. Geographical and Geological.-Dr. T. F. Allen, in a paper entitled "Similarity between the Characese of America and Asia," in the Bulletin of the Torrey Botanical Club, pointed out the resemblance between the Asiatic and American Characex. "A Summer in Roan mountain," by J.W. Chickering in the December Botanical Gazette; "A Botanist in Southern California," by J. F. James, in the July Naturalist ; "Botanizing on the Colorado desert," by E. L. Greene, in the November Naturalist; "The Timber Line of High Mountains," by Thomas Meehan, in the Proceedings of the Academy of Natural Sciences of Philadelphia, and "The Geological History of the North American Flora," by Professor Newbury, in the July Bulletin of the Torrey Botanical Club (abstract of a lecture) are the other important contributions under this section.

D. Historical.-The conclusion of Frederick Brendel's. "HisvoL, xv,-No. xir. 
torical Sketch of the Science of Botany in North America, from I 840 to 1858 ," in the January Naturalist, and the "Sketch of the Progress of Botany in the United States in the year 1879," by C. E. Bessey, in the December Naturalist, are the only historical papers published during the year.

E. Text Books, etc. - Dr. Killebrew's little book "Grasses, Meadows and Pastures," and Dr. Sturtevant's pamphlet on "Indian Corn" (reprinted from the 38 th Rept. of the N. Y. State Agricultural Society) deserve mention here on account of their botanical interest, in addition to their high agricultural value.

"Botany for High Schools and Colleges," Holt \& Co., N. Y., by C. E. Bessey, appeared early in August. It consists of two hundred pages of general anatomy and physiology of plants, followed by three hundred and seventy-five pages devoted to the special anatomy and physiology of plants, and outlines of their classification. Under the first, protoplasm, the plant-cell, cellwall, formation of new cells, products of the cell, tissues, tissue systems, intercellular spaces, plant-body, chemical constituents of plants, chemical processes in the plant, relations of plants to external agents, are successively discussed. In the second part the characters of the seven grand divisions (sub-kingdoms) of the vegetable kingdom are described; the limits of the classes, cohorts and orders are briefly outlined, and their structure illustrated by selected examples.

A second revised and enlarged edition of Volney Rattan's "Popular California Flora," was issued about the middle of the year from the publishing house of Bancroft \& Co., San Francisco. As enlarged, it consists of a hundred and fifty-six pages, including twenty-four pages of introductory matter, followed by simple descriptions of the less difficult plants selected from the flora of West-central California.

By far the most important botanical book of the year, was Sereno Watson's Vol. In of the "Botany of Californin," including Apetalæ, Gymnospermæ, Monocotyledones, Vascular Cryptogams, Musci and Sphagnaceæ. Dr. Engelmann elaborated the oaks, the pines and their allies, and the Loranthaceæ; M. S. Bebb, the willows; Wm. Boott, the Carices; Dr. Thurbur, the grasses, and Professor Eaton, the vascular cryptogams. A valuable "List of Persons who have made Botanical Collections in California," is appended, by Professor. Brewer. The two volumes of this now 
completed work, aggregating nearly twelve hundred pages, stand as a most pleasing monument to the ability of the authors on the one hand, and on the other to the generosity of the business men of California, who voluntarily defrayed all the expenses of preparation and publication.

F. Periodical Publications.-The Bulletin of the Torrey Botanical Club and the Botanical Gazette continued throughout the year as our only exclusively botanical journals. Each gave good evidence of substantial growth. The botanical departments of the American Foumal of Science and the Naturalist were maintained as usual. Botanical articles frequently appeared also in the Gardener's Monthly, American Agriculturist, American Monthly Microscopical Foumal and the American Foumal of Microscopy.

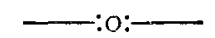

